\title{
DIE BEROEPSTAAK VAN DIE UNIVERSITEIT
}

\section{Inleiding}

Die universiteit is ' $n$ instelling wat al meermale as een van die belangrikste erfenisse van die Westerse wêreld uit die Middeleeue bestempel is. Dit tel al honderde jare en tog het daarin nie werklike wesensverandering plaasgevind nie. Hiermee word nie bedoel dat daar nie ontwikkeling op die vlak van die tersiêre onderwys gedurende al die eeue was nie. Inteendeel, daar is sonder twyfel min instellings wat so in omvang toegeneem en in wese verdiep en verfyn is as juis die universiteit - en met dit alles sonder om van aard te verander.

By die behandeling van die beroepstaak van die universiteit sal juis duidelik blyk dat hierdie faset wat vandag as baie modern voorkom, eeue gelede reeds in die universiteit aanwesig was, nie altyd in dieselfde omvang en ewe veel verantwoord nie, maar nogtans onmiskenbaar daar.

Ek is van oordeel dat juis hierdie bestendigheid van wese karaktertrek by uitnemendheid is as bewys van die selfstandigheid van die terrein van die universiteit - die eie lewenskring, samelewingsverband, wat waarskynlik sal bestaan solank daar 'n mensheid is.

Op die pad van die historie het daar wisseling van beklemtoning gekom, maar radikale verwerping van die paar wesenstrekke van die universiteit is nie bekend nie. Selfs vandag met sy wilde studente-eise dui nog nie op die aftakeling van die universiteit as sodanig nie. Daar kom radikale voorstelle in verband met universiteitsbeheer, akademiese inhoud, metode, meting, standaarde, dissipline, maar m.i. sal hierdie slinger weer terugswaai na 'n normale ewewig sodra die werklik onhoudbare situasies van 'n groot aantal universiteite van die wêreld uit die weg geruim is.

In hierdie proses kom die beroepsaspek van die taak van die universiteit ook in die gedrang na aanleiding van die koue rasionalisme en utilisme en geestesekonomie wat die jongmens van die dag in sy algemene denke beheers. Hy skep die indruk dat hy die universiteit van die beklemtoning van die dieper en breër lewenswaardes wil afdwing na die meer direk prakties gerigte, en waar hierdie houding veral uitslaan in die beroepsdwang wat hy voorstaan, vra dit ons ernstige aandag. 
Dit is egter nie die enigste rede waarom ons oor die onderhawige saak moet besin nie. Ook die volwasse lewe klop op die deur van die universiteit dat hy steeds meer en meer beroepsrigtings moet erken en die opleiding daarvoor bied, nie as ' $n$ bloot meganies-tegniese afrigting nie, maar met die wetenskaplike fundering soos elke ander erkende professie op die universitêre vlak.

Meer nog: daar is professies wat die universiteite in hulle wetenskapsbeoefening wil afdwing van die benadering van die vak as wetenskap met die uitbouing daarvan as sy eerste taak na 'n vakbenadering in die lig van die behoeftes van die professie al sou dit lei tot so 'n verminking van die vak dat die student nooit ' $n$ begrip van die wese, aard en struktuur daarvan sal hê nie. En dit kom van mense wat beter behoort te weet soos onderwysdepartemente, regsgeleerdes, medici.

Dit is nie die eerste maal dat die universiteit met hierdie saak te doen kry nie. Was hy dan nie oorspronklik niks anders as 'n beroepskool vir teoloë, medici en regsgeleerdes nie?! En wat dan nog aan hulle sertifikate uitgereik het wat aan hulle die reg verleen het om onderrig in daardie vakke te gee dus deur en deur beroepsgerig!

Keer ons dan nou na 'n meer sistematiese benadering van ons onderwerp.

\section{Die vraagstuk van beroepsopleiding}

Is dit wel 'n funksie van die universiteit om mense vir bepaalde beroepe op te lei? Watter beroepe sou moontlik hierby betrokke kan wees? Hoe ver moet met beroepsopleiding aan die universiteit gegaan word? Moet die hele opleiding beroepsgerig wees of moet die beroepsy in mindere of meerdere mate sporadies by die wetenskapsbeoefening bygebring word? Moet die universiteit nie 'n wesentlike verandering in sy samestelling ondergaan om 'n losse gemeenskap van beroepskole of -institute te vorm nie? Of moet juis van hierdie gedagte so ver as moontlik weggebly word?

Hierdie vrae dring deur na die wese en funksies van die universiteit. Dit is nie moontlik om ligweg op grond van studenteagitasie of die van sekere professies hierdie instelling van 'n eeue oue koers af te dwing nie.

Die universiteit as inrigting lê ingebed in die menslike 
gemeenskap wat in sy samestelling en sug na behoeftevervulling nie afhanklik is van willekeurige besluite van groepe daarbinne of nog erger daarbuite nie. In daardie opset vind ons 'n patroon van behoeftes wat met die eeue geweef is en wat ten diepste verband hou met die menswees van die lede van die maatskappy. Ons mag hier geen geweld aandoen sonder om die vrug van die rewolusie te maai nie.

Ons kan met die omskepping van die universiteit alleen so ver gaan as wat met die menslike samelewing bestaanbaar is.

Met hierdie gedagte van bestendigheid as die agtergrond kan ons nou gaan kyk na die wese en funksies van die universiteit om die plek van die beroepsopleiding daarin te bepaal.

\section{Die wese en funksie van die universiteit met besondere aandag aan sy beroepstaak}

Aangesien die wese en funksies van die universiteit al meermale en op verskeie plekke breedvoerig uiteengesit is, volstaan ons hier met breë trekke om te kan kom by die vraagstuk van hierdie voordrag.

Die universiteit lê op die terrein van die maatskappy met ' $n$ heel besondere opset om langs 'n eeue-lange geykte weg in daardie behoeftes van die gemeenskap te voorsien wat deur geen ander instelling behartig kan word nie. Die universiteit het sy eie terrein van werksaamhede wat wesentlik van die van elke ander instansie verskil. Die geskiedenis bied etlike voorbeelde van pogings om behoeftes aan die universiteit bevredig te kry wat nie in sy opset pas nie omdat dit in 'n ander dimensie lê en telkens het die universiteit dit verwerp soos die menslike liggaam vreemde elemente.

Hieruit moet ons aflei dat daar nie willekeurig met die universiteit rondgespring mag word nie; alleen die dinge wat wesentlik daar tuis hoort gedy daar. En dit is alles wat wesentlik geassosieer met die wetenskap op die hoër vlak daarvan lê. Dit sluit vanselfsprekend in die sistematisering van die wetenskaplike kennis en die oordrag daarvan aan die volgende geslag van hulle wat in staat is daartoe en dit begeer om op die vlak van die geleerdheid te beweeg; die verdere uitbouing van die wetenskap deur navorsing in al sy vorme en sy volle omvang; die ontwikkeling en vorming van mense in die laaste fase van 
die adolessensie; die toerusting van die volgende geslag vir die sogenaamde hoër professies van die volkshuishouding; en die beoefening en oordrag van kuns en kultuur op 'n gevorderde vlak van die gemeenskap.

Geen ander inrigting het hierdie opset nie; daar is wat een of ander van hierdie funksies vervul maar dan nog nie in dieselfde komplekse opset van die universiteit nie waar die afsonderlike funksies steeds geintegreerd in die geheel beoefen word sodat voortdurend onderlinge bevrugting tot die volle rypheid en rykdom van daardie inrigting voer. En juis dit alles skep die eie-aardige instelling bekend as die universiteit.

Enkele voorbeelde sal hierdie stelling kan bevestig en verhelder. Die kolleges vir gevorderde tegniese onderwys bied sekere parallelle kursusse met die van die universiteite aan op die vlak van die beroepsonderwys. Hierdie opleiding word egter geīsoleerd van die wetenskap in sy breedte en diepte aangebied. Dit vereis sekerlik geen betoog om te begryp dat die twee dus hemelsbreed in hulle benadering, inhoud, metode en resultaat sal verskil nie. Ook onderwyskolleges beweeg op die vlak van die nie-universitêre inrigtings. Diegene wat die verskil tussen universiteite en kolleges sien in die reg om grade toe te ken of nie het voorwaar hoegenaamd geen begrip van een van die twee inrigtings nie.

Navorsingsinstitute doen ook wetenskaplike navorsing en wel dikwels los van universiteite. Vanselfsprekend sal hier 'n radikale verskil gekonstateer moet word omdat daar in die geval van die selfstandige institute geen sprake van beinvloeding van die kant van die sistematisering om by die rypende menslike intellek of breër geestelike funksionering in te skakel en van die opvoedingsituasie en van die beroepseise is nie. Hulle neig dan hoofsaaklik na toegepaste navorsing terwyl die universiteite hierbenewens telkens afdaal na die basiese vir die finale en onontbeerlike fundering van alle navorsing. Dit is tog te betreur dat in ons land - en ook elders in die wêreld so ' $n$ groot deel van die wetenskaplike navorsing nie aan universiteite gedoen word nie. Ek is oortuig daarvan dat 'n sterk saak uitgemaak kan word teen die bestaan van sodanige instellings, en dit lê op die weg van die universiteite van ons land om hierdie saak na te vors en in sy regte perspektief te stel tot heil van alle betrokkenes.

Om terug te keer tot die funksies van die universiteit en 
wel die beroepsaspek daarvan: Van die eerste funksies wat die universiteit verrig het was soos ons reeds aangetoon het, om mense op te lei vir bepaalde vaste en goedomlynde professies: teoloë, medici, regsgeleerdes, en dan nog het hulle 'n sertifikaat ontvang wat hulle gemagtig het om onderrig in hulle bepaalde spesialisasie te gee - dus nog 'n verdere beroep naas die genoemde drie. Die gemeenskap se eerste behoefte wat op die universiteit uitgeloop het was dus nie om wetenskap as sodanig te bekom nie maar om met hierdie opleiding in staat gestel te wees om 'n bepaalde beroep te kan beoefen.

En so was dit deur die eeue heen tot vandag toe, selfs in tye toe die universiteite hulleself in ivoortorings afgesluit het van die wêreld om die wetenskap in selfingenomenheid te beoefen, het hulle mense vir beroepe opgelei minder of meer doeltreffend. Telkens moes daar maar weer na die professionele toerusting teruggekeer word omdat die gemeenskap dit van die universiteit met reg geëis het. Daar moet iewers 'n ewewigspunt tussen die akademiese en die professionele bestaan en ons beskou hierdie saak kortliks aan die hand van die huidige praktyk aan die universiteite.

Dit is opvallend hoe uiteenlopend die verskillende praktyke aan ons universiteite is; om enkeles te noem:

1. Daar is hele fakulteite wat deur en deur om een beroep sentreer en daarop gebou is: medisyne, regsgeleerdheid, teologie, tandheelkunde, ingenieurswese, veeartsenykunde, onderwys om die lys nie uit te put nie.

2. Party van hierdie fakulteite werk nie met die volle wetenskap (basies) nie, dog beweeg slegs op die toegepaste vlak daarvan wanneer dit gaan om die eerste kwalifikasie van die student terwyl die verdere grade wel deurtastend is - dit geld by uitnemendheid vir die statusfakulteite ingenieurswese en medisyne asook landbou en tandheelkunde om die opvallendste te noem.

3. Daar is fakulteite waaraan beswaarlik enige direkte beroep verbind kan word soos Lettere en Wysbegeerte en Natuurwetenskappe; hulle bedien ' $n$ horde beroepe en tog nie een direk nie. Hiermee staan ons op die moeilikste vlak van die beroepstaak van die universiteit maar ek is nie so seker of dit nie ook die vrugbaarste op hierdie gebied is nie. Ons kom egter hierop terug. 
4. Vir party beroepe word as eerste kwalifikasie grade uitgereik, vir ander diplomas en vir nog ander grade sowel as diplomas.

Om enigsins 'n verantwoorde standpunt te kan stel oor die beroepstaak van die universiteit moet ons hierdie vraagstuk meer sistematies benader volgens die verskillende fasette daarvan wat natuurlikerwys hierby te pas kom. Hier gaan dit om die doelstellings, inhoud, metode, organisasie en die dosent van beroepsonderwys aan die universiteit bepaaldelik wat sonder twyfel radikaal verskil van beroepsonderwys in ander inrigtings.

\section{Doelstellings}

Die doelstellings van die universiteit sluit ten nouste by die funksies daarvan aan. Albei is ook ewe geïntegreer in mekaar sodat elke funksie en elke doelstelling steeds aan krag, kleur en waarde toeneem soos hulle funksioneer - hulle kan nooit onafhanklik van mekaar gesien word sonder om aan waarde te verloor nie. So is die opvoedingsfunksie en -doel nie los te mak van die navorsingsfunksie en -doel, van die beroepsfunksie en -doel, van die kultuurfunksie en -doel en reg deur almal wat ons reeds hierbo genoem het.

As ons dit dan het oor die doel met beroepsopleiding aan die universiteit moet ons dadelik besef dat ons hier net soos elders met twee groepe doelstellings te doen het: algemene wat die besondere wat vir beroepsopleiding alleen geld, insluit. Elke student is volledig student vir watter beroep hy ook al voorberei word. Daarom integreer ons vir groter praktiese duidelikheid en hanteerbaarheid die twee soorte doelstellings. Hieruit moet dit duidelik wees dat die universiteit onder geen omstandighede na beroepsafrigting afgerem mag word nie, maar ook dat beroepsopleiding nie as ' $n$ minder belangrike aspek van die universitêre werk geag mag word nie.

Die hoofdoel is om beroepsopleiding te verhef tot die verhewe vlak van alle akademiese werk; om dié opleiding te laat deel in al die doelstellinge van die universiteit sodat die beroepsman opgevoede kultuurmens sal wees, wetenskaplike by uitnemendheid, navorser met die onontbeerlike toerusting daartoe; roepingsbewuste beroepsman; mens van God vir elke goeie werk volkome toegerus. 
Elkeen van hierdie fasette van die doel met die beroepsopleiding verteenwoordig 'n veelheid van besonderhede waarop hier nie breedvoerig ingegaan kan word nie. U sal my egter vergun om op een daarvan enigsins nader in te gaan omdat dit m.i. die wese van hierdie opleiding raak, sonder om te impliseer dat die ander doelstellinge minder belangrik is nie. Ek bedoel hier die doelstelling om 'n wetenskaplike beroepsman te kweek.

By hierdie opleiding gaan dit om daardie beroepe wat ons gewoonlik die professies noem en waarvoor algemeen aanvaar word dat wetenskaplike kennis 'n noodsaaklike onderbou daarvan moet wees. Hierdie aanduiding is enigsins vaag en dui daarop dat die universiteite self hieraan aandag sal moet gee om tot helderheid te kom oor wat wesentlik op hierdie vlak lê, nl. die grense tussen wetenskap, toegepaste wetenskap en praktyk. Daar is 'n verskeidenheid van terreine waarop al drie voorkom en daar telkens slegs graduele verskille kan geld.

Enkele voorbeelde sal hier van pas wees:

1. Natuurwetenskap, toegepaste natuurwetenskap, tegnologie en/of tegniek. Die persoon in die laboratorium kan tegelyk wetenskap beoefen, toegepaste wetenskap, tegnologie en tegniek. Kan hier 'n duidelike saak uitgemaak word waar die wetenskaplike onderbou nie meer noodsaaklik is nie?

2. Uit Lettere en Wysbegeerte: Watter aspekte of van watter punt af moet dit aanvaar word moet administratiewe en organisatoriese werk of personeeldiens of watter van die groot spektrum beroepe wat deur hierdie fakulteit bedien word 'n wetenskaplike onderbou hê en watter vlakke daarvan kan daarsonder klaarkom?

3. Waar lê die grens in die ekonomiese beroepe waar die wetenskaplike grondslag noodsaaklik of onnodig is? Is dit nie opvallend hoe dikwels die handel en die nywerheid mense in diens neem met lettere-en natuurwetenskaplike opleiding sonder om enigsins 'n saak teen ekonomiese opleiding te hê nie?

Hulle soek na iets anders as juis die eng beroepsafbakening. En dit werp lig op die doelstelling met beroepsopleiding: die alsydige wetenskaplike beroepsman met die gawe van die wetenskaplike gesindheid en metode wat as metodemaker in 
talle opsigte sy opleiding in ' $n$ verskeidenheid van vertakkinge $k a n$ in toepassing bring. Hierdie verhewe doelstelling moet ons enigsins nader besien om daarna te kom tot die aanduiding wat nie met hierdie opleiding beoog word nie.

Dit gaan hier om die wetenskaplike gesindheid en metode en die verskynsel metodemaak wat in die beroep in toepassing gaan. Wetenskaplike gesindheid of ingesteldheid word opgebou uit gewoontes, denkwyses en metodes, d.w.s. daardie aspekte van die menslike geestesgoedere wat hy verwerf wat in meer as een terrein in toepassing kan gaan. Of soos dit in die psigologie uitgedruk word: wat oordraagbaar is en nie vir net een bepaalde geval geld nie.

Hierdie doelstelling wil dus nie resepte verskaf wat onder sekere voorgeskrewe omstandighede toegepas kan word nie, maar wel geestesgawes bybring wat orals ewe goed toegepas kan word om die mens as 'n gevormde wese voort te bring wat nugter kan oordeel.

Hoe ver hierdie saak strek blyk duidelik as ons ag gee op wat bedoel word met iemand wat 'n wetenskaplike is: Dit is iemand

wat lief is vir die waarheid

met 'n drang om navorsing te doen

met die vermoë om nie onmiddellik te oordeel nie

met die moed om te volhard

met die geduld om noukeurig waar te neem

met die vermoë om onbevooroordeeld te wees

met onpartydigheid

kritiese houding

onemosionele optrede

noukeurigheid

versigtigheid

oordeelkundigheid.

Word hierdie hoedanighede by die mens vasgelê dan bestempel ons hom as 'n wetenskaplike. Word hy in enige beroep van toepassing geplaas dra hy al hierdie vermoëns oor in toepassing op sy beroep. En dis die groot oogmerk van univer. sitêre beroepsopleiding.

Uit die wetenskaplike gesindheid en metode kom daar onontbeerlik na vore die karaktertrek of houding om steeds, in watter verband die mens ook al staan, - ook in sy nering - 
bewus en selfs onbewus te werskaf, te arbei aan die metode van die situasie waarin hy verkeer, in sonderheid in die van sy beroep. En dit vorm deel van die doelstelling van die beroepsopleiding aan die universiteit dat die student opgeskerp moet word om so 'n krities-bouende houding in sy beroep te verwerf. Eers wanneer die beoefenaar van 'n beroep tot hierdie hoogte gestyg het, kan hy werklik leiding in sy groep neem.

Hierdie verhewe doelstelling met die beroepsopleiding skakel dan meteen bepaalde oogmerke wat soms op hierdie vlak gehuldig word uit: veral die oogmerk van afrigting waarin die mens opgelei en toegerus word om sy beroep so meganies moontlik te beoefen. Dit mag goeie vrugte afwerp in beroepe waar dit hoofsaaklik van 'n operateursaard is wat eintlik niks aan die denke oorlaat nie en wat wel seker nie as beroep met 'n wetenskaplike onderbou bestempel kan word nie. En tog is daar inrigtings wat selfs met onderwysers-opleiding naby aan hierdie afrigting kom: metodes word vir elke denkbare situasie aangebied en wanneer daar 'n variasie gedurende 'n klas opduik is die onderwyser nie by magte om die aan- of bypassing te makk nie omdat hy geen metodemaker is nie. Hiermee staan ons oneindig ver van die wetenskaplike benadering van die beroep.

Die beroepsdoel moet dan so wyd as die volkshuishouding wees omdat hy wat die wetenskap beoefen en bou ook die beste in staat is om die seëninge van die wetenskap in die volkslewe in te dra. Vanselfsprekend sal hieraan perke wees soos met alle onderwysondernemings tans ook die geval is. Daar mag egter nie vooraf op 'n arbitrêre wyse grenslyne getrek word om sekere beroepsrigtings willekeurig uit te skakel nie.

Ek is bewus daarvan dat die huidige universiteit, miskien my eie ook, in hierdie stadium so 'n benadering as in stryd met die universiteitswese sal beskou. Met groot verbetenheid word talle beroepe afgewys met die voorwendsel dat standaarde gehandhaaf moet word en dat moontlike sataliet-institute hier groot skade kan berokken waar die argument juis moes wees dat die hoë peil van die universiteit hulle sal veredel.

Hier lê 'n groot terrein vir navorsing braak om vas te stel hoe die universiteit ten beste met sy ontdekkinge, met sy hele bedrywigheid die lewe kan instap om tot 'n seën te wees 
vir een en almal, onbeperk en ongeag die huidige status van beroepe.

\section{Inhoud}

Die inhoud van die universitêre werk word tans grootliks deur die inhoud van die wetenskap as sodanig bepaal, met as uitsondering daardie gebiede waarop sekere georganiseerde professies eise in hierdie verband stel. Oorspronklik was dit nie so gesteld met die inhoud van die wetenskap nie, al was die moontlikheid daarvan soveel groter en die inhoud soveel enkelvoudiger dat dit eintlik vanselfsprekender was. En tog was hierdie benadering in embrio aan die begin aanwesig, getrou aan die wese van die universiteit as inrigting vir die beoefening van die wetenskap.

Opvoedkundige navorsers is dit eens dat die stof van die universitêre onderwys grotendeels reeds van die laat klassieke oudheid af kom en wel in die vorm van die artes liberales wat die opleiding van die begaafde Romein uitgemaak het, die kundigheid wat aan die vryman betaam het in teenstelling met die artes mechanicae of handwerke wat geskik was vir die arbeider - ' $n$ baie duidelike beroepsdifferensiasie ouer as ons jaartelling!

En hieruit het in die Middeleeue die universitêre inhoud ontwikkel: die sewe vrye kunste in hulle tweeërlei groepering

1. die trivium:

grammatika (taalkunde)

retoriek (spreekkuns)

dialektiek (redeneerkunde)

2. die quadrivium:

aritmetiek

geometrie

astronomie

musiek.

Uit die trivium ontstaan die moderne geesteswetenskappe: uit grammatika letterkundige en historiese wetenskappe; uit retoriek akademiese regskunde en uit die dialektiek die wysgerige vakke; uit die quadrivium die wis- en sterrekundige wetenskappe, die natuurkunde met alles wat dit insluit ook die skeikunde en die biologiese wetenskappe - die sogenaamde 
praktiese wetenskappe; uit die musiek die musiekleer.

In die Middeleeue is die artes liberales nie as scientiae beskou nie maar as voorbereiding daarvoor; die scientiae was teologie, regte en medisyne.

Deur die eeue het hieruit die komplekse opset van die moderne universiteil ontwikkel. Vandag word die inhoud van die universiteit - die leerplan sowel as die leergang - geregverdig op grond van die doelstellinge en funksies van die universiteit: wetenskapsbeoefening, opvoeding en beroepsopleiding.

Verder uitgebou word hierdie gronde saamgevat in die erkende wetenskaplike beginsels of kriteria vir die inhoudskeuse: die filosofiese, opvoedkundige, historiese, psigologiese, sosiologiese, korrelasie en die ekonomiese.

Om dan 'n gedrae kultuurmens en wetenskaplike te vorm is nodig nadat hierdie beginsels toegepas is om die volgende vakke in die kurrikulum van die jong mens op te neem, nie noodwendig almal op die universitêre vlak nie:

die natuurkundige wetenskappe

die biologiese wetenskappe

die historiese wetenskappe

die sosiale wetenskappe

die filosofiese wetenskappe

die religieuse wetenskappe.

Die opgeleide vir 'n beroep op die universiteit is ook so ' $n$ mens en daarom geld hierdie inhoudkriteria en wetenskapskategorieë ook vir hom. Sy studie-inhoud moet net so wyd vertak en diepgaande as die van enige ander student wees. Dit kan nie anders nie as ons teruggryp na die doelstellings wat ons hierbo gestel het.

Maar ons moet tog ook hier nader aan die verband van beroep en inhoud kom. En in hierdie verband moet dit voorop gestel word dat die beroepsvereistes onder geen omstandighede bepalend vir die universitêre inhoud, leerplan sowel as leergang, mag wees nie. Laat dit duidelik wees dat die struktuur van die wetenskap as geheel en van elke vakwetenskap afsonderlik dié bepalers van die inhoud moet wees en dat die beroep eintlik daardeur bepaal en gemaak word. Dit wil egter nie sê dat beroepsbehoeftes glad nie in ag geneem moet word nie; inteendeel, dit moet wel maar oordeelkundig en hoe dit te pas 
kom soos ek verderaan sal probeer aantoon.

Die praktiese opset alleen maak dit al onmoontlik in die geval van die meeste beroepe omdat baie beroepe van dieselfde vakke gebruik maak as hulle inhoud. In so 'n geval sou daar maklik 'n tiental variasies van dieselfde vak vereis kan word. Daarom geld vandag beroepsbemoeiing eintlik slegs op gebiede wat uitsluitlik vir een beroep of 'n groep aanverwante beroepe geld. Maar ook in hierdie gevalle is ek van oordeel dat dit nie in lyn met die akademiese opleiding van beroepsmense lê dat die beroep so 'n bepalende rol by die inhoudsvasstelling speel nie. Die doelstellinge hierbo uiteengesit kom sonder twyfel hiermee in gedrang en ook die resultaat wat bereik word.

Die kurrikulum vir 'n beroep het as gevolg van die behoeftes van beroepe vir baie jare al probleme aan die universiteit veroorsaak. Dit blyk veral duidelik uit die praktyk wat mettertyd ontstaan het waarvolgens die eerste graad saamgestel word na die eise van die wetenskap: saamvoeging van hoofvakke en ondersteunende byvakke sodat die kurrikulum 'n wetenskaplik verantwoorde eenheid in sy veelheid vorm, en waarin die spesifieke beroepseise nie in ag geneem word nie. $\mathrm{Na}$ die graad is dan voorsiening gemaak vir 'n professionele diploma waarin die beroep ten volle in ag geneem is en die inhoud dienooreenkomstig saamgestel is.

Die jongste variasie wat meer en meer veld begin wen is 'n sogenaamde geintegreerde graad waarin die akademiese en die beroepsbehoeftes opgeneem word en dan met 'n jaar verleng is. Hier is sonder twyfel ' $n$ poging om die praktiesprofessionele te verhef tot die vlak van die akademiese en maak daarmee die pad oop vir die opname in die akademie van steeds meer en meer praktiese terreine wat nie sonder meer as akademies bestempel kan word nie. Waar sal die streep getrek word?

My standpunt is die geassosieerde instituut om die akademie wesentlik akademies te hou.

Met hierdie standpunt wil ek nie voorgee asof daar geen akademiese aspekte of fasette in die beroepe aanwesig is nie. Inteendeel, is ek oortuig daarvan dat aan haas elke beroep ' $n$ mate van akademiese inhoud verleen word maar dit kwalifiseer sodanige opset nog nie as geregtig op 'n graad nie. Dit mag teenstrydig klink maar ek het hier veral op die oog die inhoud van die metodeaspek van die beroep wat ek meen daarvoor 
kan kwalifiseer. In die kurrikulum van die beroepskursus moet dit dan ook ' $n$ besondere plek beklee.

Beroepskwalifikasie kan na die eerste kwalifikasie op die vlak van die akademie gaan en grade uitreik maar dan moet dit wetenskapsbeoefening deur en deur wees en nie beroepsopleiding nie.

Dit het $u$ ongetwyfeld opgeval dat op hierdie terrein daar baie vraagstukke is wat om antwoorde vra wat net nie kan gegee word nie. Hier weer het die universiteit ten taak om die situasie na te vors en tot die beste oplossing te geraak. Wanneer daar tans oor 'n graad plus diploma of vierjarige graad besluit moet word, val dit op dat daar meer op gevoel afgegaan word as op wetenskaplik verantwoorde regverdiging.

\section{Metode}

Die doel en die inhoud van die beroepsopleiding is die bepalers van die metode wat in die opleiding toegepas word. En die metode van die universiteit is met die wese van die inrigting een: die wetenskap moet ten alle koste op elke vlak tot sy reg kom en van hier uit word verskillende doelstellinge beoog, inhoude bepaal en dienste gelewer soos ons gesien het.

Universitêre metode is dus wetenskaplike metode en hiervan mag nie afgewyk word nie, ook nie in beroepsopleiding nie. Te alle tye en onder alle omstandighede moet hierdie metode toegepas word:

in die beoefening van die wetenskap by die oordrag van

kennis sowel as navorsing

in die opvoeding van die mens

in die opleiding vir ' $n$ beroep.

Die kenmerke van die wetenskaplike metode wat algemeen geld, moet ingedra word in die metode van die beroep. Hierdie oordrag moet finaliter deur die student gemaak word nadat die wetenskaplike gesindheid by hom gevestig is. Hy moet sodanig gevorm word dat hy op skerpsinnige wyse sy beroep kan ontleed en dit bevrug vanuit die wetenskap wat hy met die oog daarop bestudeer het.

Soos ons reeds vroeër opgemerk het is wetenskaplike gesindheid die oordraagbare element by uitnemendheid op 'n legio terreine. Daarom dat so baie beroepe geen eise t.o.v. bepaalde vakinhoud stel nie en selfs nie eens vir 'n bepaalde graad 
nie solank die persoon daardie wetenskaplike gesindheid as Imetode aangekweek het. En daarmee saam die toegewydheid vir die beroep wat ons bestempel as roepingsbewustheid.

Ons gaan enigsins nader in op die wetenskaplike metode. Volgens Coetzee bestaan hierdie metode uit die bekende ses trappe:

1. Die ontstaan van 'n besefte moeilikheid;

2. die bepaling van die moeilikheid met die oog op 'n vraagstelling (probleemstelling);

3. die vinding van ' $n$ moontlike verklaring (hipotese);

4. die logiese uitwerk van die moontlike verklaring of oplossing;

5. die bevestiging van die oplossing deur nadere toetsing en die formulering van ' $n$ formele samevatting;

6. die beoordeling van die gevormde oplossing in die lig van toekomstige behoeftes en eise.

Pas ons hierdie selfde metode toe op die bestudering van die metode van die benadering van die beroep op die universiteit is dit begryplik dat ons hier 'n beroepsmens kweek met ' $n$ besondere ingesteldheid en bewustheid teenoor sy beroep. Dit verhef die hele opleiding finaal bo die kader van die afrigting en plaas dit onvoorwaardelik in die sfeer van die akademie. Dit maak van die student metodemaker in sy beroep wat die hoogste waarborg vir die skerpsinnige beoefening van die beroep is, wat die enigste weg is om elke betrokke professie op 'n vlak van die meester te plaas.

Ek is van oordeel dat dit wel seker nie so bewustelik en uitgesproke nie maar tog wel so deur die Middeleeue aangevoel is. En tot vandag is die gemeenskap meer en meer daarop ingestel dat sekere beroepe alleen langs hierdie weg ten beste in sy midde beoefen kan word.

\section{Organisasie}

In 'n sekere sin kan gesê word dat hierdie saak geen besondere organisatoriese aspekte het nie en dat die beroepstaak eenvoudig in die gewone opset van die universiteit as geheel opgeneem kan word. Dit is veral waar van die wetenskapsaspek van die beroep wat deur die beoefening van die wetenskap in die algemeen bygebring word. 
Indien daar by die bepaling van die inhoud van die kursus al beroepsbehoeftes bygebring word, ontstaan daar egter onmiddellik organisatoriese vraagstukke veral met die oog op die aanbieding van verskillende akademiese kursusse vir verskillende beroepe. In sommige vakke kan dit uitloop op 'n absurde aantal variasies om in die behoeftes te voorsien.

Organisatories moet daar ernstige aandag aan die professionele inhoud en metode gegee word omdat dit, alhoewel geĩntegreer in die akademiese vakinhoud, tog 'n eie moet hê wat uit daardie beroep of groep beroepe kom. En dan gaan dit om toerusting in sy hele wye omvang van geboue tot apparaat en personeel met alles wat daarmee saamhang. Dit bly egter nog redelik maklik hanteerbaar solank dit gaan om beroepe wat of hele fakulteite beslaan of waarvan almal oortuig is dat hulle 'n akademiese onderbou moet hê.

Die saak word egter aansienlik ingewikkelder wanneer 'n verskeidenheid beroepe in dieselfde fakulteit (om nie te praat van vak nie!) tereg moet kom of wanneer bepaal moet word waar die grens lê vir die aanvaarding van 'n beroep vir universiteitsopleiding.

Organisatories sou hierdie probleme m.i. die beste beredder kon word in institute wat op ' $n$ bepaalde wyse aan die universiteit verbind is, aangeneem dan dat die akademiese en die professionele nie deurmekaar in dieselfde jare geplaas word nie. Dit sou meteen baie twyfelagtighede in ons huidige stelsel uit die weg ruim. Ek meen dat my bedoeling so duidelik is dat ek nie verder hierop nou hoef in te gaan nie. Daarmee beweer ek geensins dat ek die stelsel in orde het nie. Dit is ongetwyfeld 'n terrein wat besondere navorsing van die kant van die universiteit sal verg, voordat dit grootskaals toegepas sal kan word.

So 'n stelsel sal m.i. die nodige waarborg vir akademiese standaarde bied. Daar sal hierom selfs vir beroepe waarvoor tans glad nie aan die universiteite opleiding verskaf word nie voorsiening gemaak kan word. Laat ek 'n enkele betwisbare voorbeeld noem, betwisbaar omdat dit volgens aller oordeel op die vlak van die handvaardigheid of ambagte lê. Ek wil dit oor houtwerk hê sonder enige bybedoelings van selfregverdiging!

Ek weet nie wie van u kennis dra van die twee Britse kwalifikasies in hierdie verband nie, die M.Coll.H. (Member of the College of Handicrafts) en die gevorderde F.Coll.H. (Fellow). Wie met die houers van hierdie kwalifikasies te make gekry het, 
het onmiddellik onder die besef gekom van 'n paar eienskappe wat hulle besit het wat beslis nie as blote handvaardigheid bestempel kan word nie: werklike wetenskaplike kennis van hout in sy ryke verskeidenheid en in sy aanwending, wetenskaplike kennis van gereedskap en die gebruik daarvan, ook fyn kunsgevoel en ontleding wat selfs uit die blote streling van die hand oor die edele stuk hout spreek - 'n gawe en 'n ontwikkeling wat in lyn lê met ander vorme van kuns, die beoefening waarvan aan die universiteit nooit bevraagteken word nie.

En so is daar meer voorbeelde op die tegnologiese en tegniese vlakke wat in so 'n instituut tot volle ontplooiing kan kom onder die invloed van die akademie.

\section{Die dosent en die beroep}

Dit kan aanvaar word dat elke vak aan die universiteit in diens van meer as een beroep staan, trouens in 'n veelheid beroepe waarvan die beoefenaar van die vak - die dosent - uit die aard van die saak nie besondere kennis kan dra nie. En tog moet hy meewerk om beroepsopleiding te verskaf.

Dit is egter in die lig van hierdie betoog geen probleem nie omdat hy wetenskaplike in sy vak moet wees om van die student te maak wat dusver gestel is. Wat wel hierby kom is dat die dosent bewuste opvoeder moet wees om daardie gesindhede by die student te kweek wat te gelegener tyd in toepassing in die beroep kan gaan.

Dit vereis ons van die dosent wat vir die eerste graad oplei wat nie direk beroepsgerig is nie. Word die beroepsopleiding in die eerste graad geïntegreer verander die posisie met hom ingrypend. Dan word van hom dieselfde verwag as van die dosent vir die beroepsgerigte diploma voor of na die graad.

Hierdie opleiding kan alleen behartig word deur akademies deeglik opgeleide en professioneel deurgewinterde dosente. Die hele betoog tot dusver vereis dat hy self sal moet besit wat hy aan die student moet oordra: Opgevoedheid, gestudeerdheid, wetenskaplikheid, navorsingsvermoë, professioneelheid.

\section{Slot}

My navorsing van die probleem van die beroepstaak van die universiteit het my tot net een slotsom gelei en dit is dat 
dit sonder twyfel daardie aspek van die akademie is wat van die meeste in beoefening is en waarvan die wetenskaplike kennis ewe sonder twyfel die gebrekkigste is.

Ons kan maar baie min bewys van wat ons op hierdie vlak beweer. En hierdie bewerings berus hoofsaaklik op individuele en meesal sporadiese waarneming.

Sal ons Universiteit nie die voortou neem in hierdie saak ter wille van die verdere verbetering van ons eie werk (beroep!) asook tot die heil van al die beroepe waarvoor ons direk sowel as indirek oplei nie?

P.U. vir C.H.O.

H. J. J. Bingle. 